\title{
PERAN KETERAMPILAN BERPIKIR KRITIS DI SEKOLAH MENENGAH PERTAMA PADA MATERI SISTEM PENCERNAAN
}

\author{
Juniar Fauziatul Azizah ${ }^{1}$, Muzzazinah $^{2}$, Elfi Susanti ${ }^{3}$ \\ Program Studi Pendidikan Sains, Universitas Sebelas Maret ${ }^{1}$ \\ Program Studi Pendidikan Biologi, Universitas Sebelas Maret ${ }^{2}$ \\ Program Studi Pendidikan Kimia, Universitas Sebelas Maret ${ }^{3}$ \\ Email: juniarazizah01@ @student.uns.ac.id
}

\begin{abstract}
Abstrak
Keterampilan berpikir kritis artinya keterampilan berpikir taraf tinggi yang seharusnya akan dikembangkan di sekolah, sejalan dengan tujuan kurikulum 2013 revisi yang mengutamakan kecakapan abad 21 sebagai bekal hidup masa yang akan tiba. Penelitian ini bertujuan untuk menganalisis dan mengklasifikasikan level siswa dalam mengkonstruksi keterampilan berpikir kritis. Subjek penelitian adalah siswa kelas VIII B SMP Negeri 6 Ngawi tahun ajaran 2020/2021 sebanyak 28 siswa. Pengumpulan data dilakukan melalui wawancara dan tes keterampilan berpikir kritis. Metode yang digunakan deskriptif kualitatif. Instrumen tes keterampilan berpikir kritis yaitu 5 soal esai terdiri 5 indikator. Hasil tes keterampilan berpikir kritis dinyatakan valid ditinjau berdasarkan hasil validasi, tingkat kesukaran, daya pembeda, dan reliabilitas. Analisis dilakukan terhadap hasil tes siswa di setiap indikator dan dikategorikan ke dalam lima kategori berpikir kritis yang terdiri dari sangat baik (SB), baik (B), sedang (S), kurang (K), dan sangat kurang (SK). Hasil penelitian menunjukkan bahwa presentase tertinggi pada indikator berpikir kritis diperoleh sebesar $32 \%$ adalah indikator mengatur strategi taktik. Indikator berpikir kritis diperoleh presentase terendah sebesar $8 \%$ adalah indikator membangun keterampilan dasar. Hal ini membuktikan bahwa keterampilan berpikir kritis sangat perlu dilatihkan lebih lanjut agar dapat ditingkatkan dalam pembelajaran IPA dan memajukan di bidang pendidikan.
\end{abstract}

Kata Kunci : keterampilan berpikir kritis, berpikir tingkat tinggi, kurikulum 2013

\begin{abstract}
Critical thinking skills are higher order thinking skills that should be developed in schools, in line with the objectives of the 2013 revised curriculum which prioritizes 21 st century skills as a provision for future life. This study aims to analyze and classify the level of students in constructing critical thinking skills. The research1subjects1were 28 students of class VIII B SMP Negeri 6 Ngawi for the academic year 2020/2021. Data collection was carried out through interviews and critical thinking skills tests. The method used was descriptive qualitative. The critical thinking skills test instrument was 5 essay questions consisting of 5 indicators. The results of the critical thinking skills test were declared valid in terms of the 1results 1 of 1 validation, level of difficulty, differentiation, and reliability. The analysis was carried out on the student test results on each indicator and categorized into five critical thinking categories consisting of very good $(V G)$, good $(G)$, medium $(M)$, low $(L)$, and very low $(V L)$. The results 1 showed that 1 the highest percentage of indicators of critical thinking was obtained by 32\% which were indicators of tactical strategy setting. Critical thinking indicators obtained by the lowest percentage of $8 \%$ were indicators of building basic skills. This proves that critical thinking skills need to be further trained so that they can be improved in science learning and advance in the field of education.
\end{abstract}

Key Words : critical thinking skills, higher order thinking, 2013 curriculum

\section{PENDAHULUAN}

Peran pendidikan penting dalam membangun suatu peradaban bangsa yang berdasarkan atas jati diri dan karakter diri bangsa. Pendidikan harus bisa menyiapkan generasi emas untuk dapat menghadapi berbagai tantangan. Dibutuhkan siswa untuk sukses dalam konteks abad 21 adalah keterampilan dan pengetahuan [1]. Tujuan pendidikan di abad 21 yaitu dapat dikembangkan kemampuan berpikir siswa, salah satunya adalah keterampilan 
berpikir kritis. Keterampilan berpikir merupakan kemampuan yang sangat dibutuhkan dalam menghadapi tantangan kehidupan [2].

Berpikir kritis adalah proses berpikir mendalam yang menuntut kita untuk mengetahui yang benar dari yang salah melalui analisis pengalaman dan teori-teori sebelumnya [3]. Berpikir kritis merupakan suatu kemampuan berpikir secara reflektif yang berfokus di suatu pola pengambilan keputusan tentang apa yang harus diyakini, harus dilakukan dan dapat dipertanggung jawabkan [4]. Berpikir kritis yaitu aturan diri dalam suatu keputusan yang dapat menghasilkan suatu interpretasi, analisis, evaluasi, inferensi, maupun pemaparan menggunakan suatu bukti nyata, konsep, metodologi, kriteria, atau pertimbangan kontekstual yang menjadi dasar dibuatnya suatu keputusan [5].

Keterampilan berpikir kritis juga dapat dilatihkan saat proses pembelajaran daring selama pandemi pada mata pelajaran IPA tingkat SMP. Berdasarkan hasil survei di SMPN 6 Ngawi saat proses pembelajaran daring yaitu guru memberikan materi melalui Microsoft Teams, kemudian siswa mempelajari materi tersebut dan mengerjakan tugas secara mandiri dari rumah. Proses pembelajaran yang seperti ini mengakibatkan perkembangan siswa kurang terstimulasi karena dominan pada pemberian tugas, sehingga pembelajaran tidak berkesan. Hal ini tentunya akan memberikan dampak pada kemampuan berpikir kritis siswa. Saat pembelajaran secara daring difokuskan pada pendidikan karakter, serta kemampuan numerasi atau menganalisis dengan menggunakan angka dan literasi, bukan pada hasil pencapaian akademik saja [6].

Keterampilan berpikir kritis dapat diartikan sebagai suatu potensi yang dimiliki oleh setiap orang, sehingga dapat diukur, dilatih, dan dikembangkan [7]. Upaya pengembangan pada keterampilan berpikir kritis yang paling baik dan bagus dapat dilakukan dengan cara mengkaitkan materi pembelajaran yaitu pengalaman nyata siswa di lingkungan sehari-hari. Oleh karena itu, perlu adanya pengembangan keterampilan berpikir kritis siswa dalam pembelajaran ini menjadi suatu upaya untuk peningkatan hasil belajar siswa. Berpikir kritis juga memerlukan latihan khusus yaitu salah satu caranya dengan kebiasaan siswa yang mengerjakan soalsoal yang dapat mengembangkan berpikir kritisnya [8]. Oleh karena itu, dalam penelitian ini akan dibahas tentang suatu tingkat keterampilan berpikir siswa yang dapat diukur dengan bentuk soal esai yang sesuai dengan pada indikator berbasis keterampilan berpikir kritis.

Penelitian ini merupakan studi pendahuluan yang bertujuan untuk dapat mengetahui suatu kemampuan berpikir kritis siswa terhadap pada materi sistem pencernaan. Siswa cenderung sulit dalam menyerap dan mengerti apa yang akan disampaikan oleh guru, sehingga menyebabkan suatu kualitas pembelajaran biologi pada berbagai jenjang pendidikan menjadi rendah. Indikator berpikir kritis yaitu mengacu 5 indikator terdiri yaitu pada memberikan penjelasan sederhana, pada membangun keterampilan dasar, menyimpulkan, memberikan penjelasan lanjut, mengatur strategi dan taktik.

Apabila keterampilan siswa diketahui, maka akan mudah merancang rencana pembelajaran untuk dapat melatihkan keterampilan yang masih kurang. Selain itu, keterampilan berpikir kritis tidak hanya dapat dilakukan dalam suatu pembelajaran saja, tetapi juga harus didukung dengan adanya instrumen penilaian siswa, sehingga dapat mencerminkan diri di siswa pada keterampilan berpikir kritis. 
Berdasarkan uraian di atas, peneliti tertarik untuk melakukan suatu analisis dan mengklasifikasikan level siswa dalam mengkonstruksi keterampilan berpikir kritis. Hal ini dilakukan sebagai evaluasi proses pembelajaran. Selain itu juga untuk masukan terhadap tenaga pendidik untuk dapat menyusun sistem pembelajaran yang dapat meningkatkan kemampuan berpikir kritis siswa SMP.

\section{METODE}

Jenis penelitian yang digunakan adalah deskripstif kualitatif. Penelitian ini dilaksanakan di SMP Negeri 6 Ngawi tahun ajaran 2020/2021. Subjek penelitian adalah siswa kelas VIII B sebanyak 28 siswa. Instrumen yang digunakan dalam penelitian ini berupa 5 butir soal keterampilan berpikir kritis. Keterampilan berpikir kritis diukur terdiri dari 5 indikator yaitu terdiri dari memberikan penjelasan sederhana, pada membangun keterampilan dasar, pada menyimpulkan, memberikan penjelasan lanjut, mengatur strategi dan taktik. Kelima indikator tersebut terdapat dalam 5 butir uraian yang telah diuji validitas, tingkat kesukaran, daya pembeda, dan reliabilitas pada tes hasil tes profil awal keterampilan berpikir kritis siswa.

Pengumpulan data dalam penelitian ini dilakukan melalui wawancara dan tes keterampilan berpikir kritis. Hasil tes siswa untuk menentukan suatu ketercapaian pada tiap indikator kemampuan berpikir kritis dihitung menggunakan rumus berikut:

$$
\text { Persentase }=\frac{\text { skor perolehan }}{\text { skor maksimal }} \times 100 \%
$$

Nilai presentase keterampilan berpikir kritis yang dapat diperoleh dari suatu perhitungan di atas akan dikategorikan sesuai pada Tabel 1 .
Tabel 1. Kategori Persentase Keterampilan Berpikir Kritis

\begin{tabular}{cc}
\hline Interpretasi (\%) & Kategori \\
\hline $81,25-100,00$ & Sangat Baik (SB) \\
$62,50-81,25$ & Baik (B) \\
$43,75-62,50$ & Sedang (S) \\
$25,00-43,75$ & Kurang (K) \\
$<25,00$ & Sangat Kurang (SK) \\
\hline
\end{tabular}

\section{HASIL DAN PEMBAHASAN}

Berdasarkan hasil penelitian diperoleh bahwa suatu keterampilan berpikir kritis pada materi sistem pencernaan terdapat 5 indikator yang telah dilakukan dengan menunjukkan pedoman perolehan hasil penelitian, analisis perolehan tes berpikir kritis dapat disajikan pada Tabel 2.

Tabel 2. Analisis Jawaban Siswa Dari Indikator Keterampilan Berpikir Kritis

\begin{tabular}{|c|c|c|}
\hline $\begin{array}{c}\text { Indikator } \\
\text { Keterampilan } \\
\text { Berpikir Kritis }\end{array}$ & $\begin{array}{c}\text { Interpretasi } \\
(\%)\end{array}$ & Kategori \\
\hline $\begin{array}{l}\text { Memberikan } \\
\text { penjelasan sederhana }\end{array}$ & 11 & $\begin{array}{l}\text { Sangat } \\
\text { Kurang (SK) }\end{array}$ \\
\hline $\begin{array}{l}\text { Membangun } \\
\text { keterampilan dasar }\end{array}$ & 8 & $\begin{array}{l}\text { Sangat } \\
\text { Kurang (SK) }\end{array}$ \\
\hline Menyimpulkan & 15 & $\begin{array}{l}\text { Sangat } \\
\text { Kurang (SK) }\end{array}$ \\
\hline $\begin{array}{l}\text { Memberikan } \\
\text { penjelasan lanjut }\end{array}$ & 28 & Kurang (K) \\
\hline $\begin{array}{l}\text { Mengatur strategi dan } \\
\text { taktik }\end{array}$ & 32 & Kurang (K) \\
\hline
\end{tabular}

Analisis jawaban siswa pada Tabel 2 menunjukkan bahwa hasil analisis tiap indikator pada keterampilan berpikir kritis siswa hasilnya masih kurang variatif, dibuktikan bahwa dari suatu tingkat taraf keterampilan berpikir kritis siswa pada tiap indikator tergolong dua kategori yaitu kurang (K) dan sangat kurang (SK). Aspek 5 indikator yang dianalisis yaitu terdiri dari untuk memberikan penjelasan sederhana, membangun keterampilan dasar, dan menyimpulkan dikategorikan pada sangat kurang (SK). Aspek indikator memberikan penjelasan lanjut, mengatur strategi termasuk dikategorikan kurang (K). 
Analisis jawaban siswa berdasarkan indikator pada keterampilan berpikir kritis menunjukkan sangat kurang bervariasi. Hal tersebut menunjukkan bahwa dapat skor persentase yang didominasi kategori sangat kurang (SK) pada indikator keterampilan berpikir kritis. Di keterampilan berpikir kritis siswa yang masih sangat kurang dipengaruhi oleh suatu proses belajar mengajar di sekolah menengah pertama yang masih pasif. Hal ini dibuktikan pada Gambar 1 berikut ini.

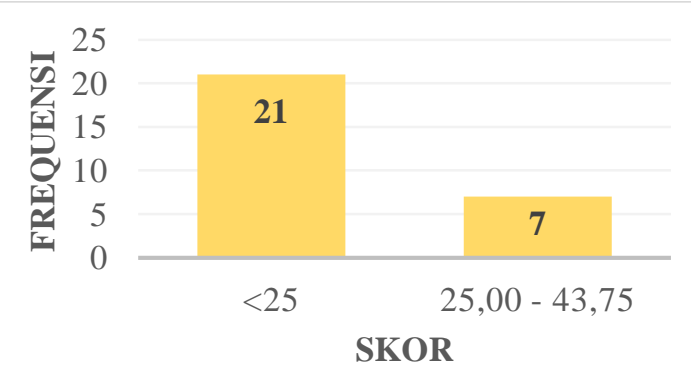

Gambar 1. Bagan Analisis Keterampilan Berpikir Kritis Siswa

Gambar 1 menunjukkan terdapat 2 kategori nilai kemampuan berpikir kritis yaitu kurang (K) dengan skor 25,00 - 43,75 berjumlah 7 siswa dan sangat kurang (SK) dengan skor $<25$ berjumlah 21 siswa. Analisis keterampilan berpikir kritis siswa dengan kategori kurang (K) sebanyak $75 \%$ dan siswa dengan kategori sangat kurang (SK) dalam keterampilan berpikir kritis sebanyak $25 \%$. Hal ini juga didukung oleh penelitian yang menyatakan bahwa suatu proses di pembelajaran tingkat SMP/MTs masih menggunakan teacher centered [10]. Dibutuhkan perubahan dalam proses pembelajaran di sekolah, sehingga dapat membuat siswa tertarik dan dapat meningkatkan keterampilan berpikir kritis siswa dan terutama hasil belajar siswa juga lebih bagus. Tidak hanya itu saja, bahan ajar yang digunakan dalam suatu proses pembelajaran juga berpengaruh terhadap berpikir kritis siswa. Dibuktikan dari hasil observasi yang menyatakan bahwa pembelajaran yang dipilih oleh guru masih membuat siswa cenderung pasif dan kurang aktif dalam proses pembelajaran [11]. Hasil analisis dari bahan ajar yang digunakan dalam suatu proses pada pembelajaran dapat dikaitkan dengan di indikator keterampilan berpikir kritis, yang dapat ditampilkan pada Gambar 2 berikut ini.

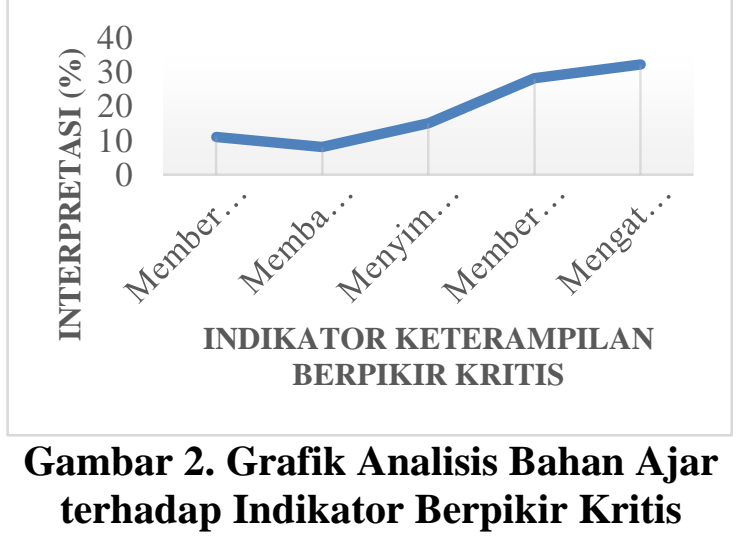

Grafik tersebut menunjukkan bahwa presentase tertinggi pada indikator berpikir kritis diperoleh sebesar $32 \%$ adalah indikator mengatur strategi taktik dan presentase terendah sebesar $8 \%$ adalah indikator membangun keterampilan dasar. Jadi bahan ajar yang akan digunakan guru memiliki kategori berpikir kritis didapat sangat kurang (SK). Hal ini membuktikan bahwa proses pembelajaran di kelas belum optimal dalam melatih berpikir kritis, sehingga keterampilan berpikir kritis siswa yang rendah dapat menimbulkan dampak yang kurang baik bagi pendidikan selanjutnya. Apabila diperhatikan sebenarnya soal yang diberikan relatif tidak sulit, hal ini berdasarkan hasil wawancara dengan salah satu guru mata pelajaran, namun siswa tetap mengalami suatu kesulitan di dalam mengerjakan soal. Berdasarkan data hasil wawancara dengan siswa diperoleh bahwa $60 \%$ siswa kurang memperhatikan informasi-informasi yang penting dalam soal, sehingga siswa kesulitan dalam menganalisis soal dan juga cenderung menghafal dalam mempelajari materi. 
Rendahnya keterampilan berpikir kritis siswa dapat mempersulit kehidupan di abad ke-21. Oleh karena itu, kemampuan berpikir kritis perlu dilatih. Hal ini sejalan dengan pendapat yang menyatakan bahwa berpikir kritis dapat diajarkan dan memerlukan suatu pelatihan untuk dapat memilikinya [12]. Terdapat beberapa strategi yang dapat digunakan guru untuk mendorong berkembangnya kemampuan berpikir kritis siswa, salah satunya adalah menciptakan kondisi untuk terjadinya interaksi di antara pelajar [13]. Terdapat upaya suatu pembentukan kemampuan berpikir kritis yang didapat optimal dengan mempersyaratkan adanya kelas yang interaktif, sehingga siswa dipandang sebagai pemikir bukan hanya seorang yang diajar, dan pengajar berperan sebagai fasilitator, mediator, serta motivator yang membantu siswa tersebut dalam belajar bukan sebagai pengajar saja [14].

Guru harus lebih kreatif dalam merancang dan dapat mengembangkan perangkat pembelajaran agar dapat mampu meningkatkan kemampuan berpikir kritis siswa, sehingga menjadi kebiasaan dalam kegiatan pembelajaran. Guru juga melibatkan siswa dalam suatu pembelajaran yang akan dapat mampu merangsang kemampuan siswa di dalam berpikir kritis melalui berbagai model pembelajaran aktif. Guru juga harus mampu menerapkan model pembelajaran yang bertujuan agar materi IPA mudah dipahami oleh siswa, sehingga dilatih berpikir kritis [15]. Guru mampu menciptakan pembelajaran yang melatih kemampuan berpikir kritis siswa sesuai potensi yang dimiliki siswa yang akhirnya dapat meningkatkan kemampuan berpikir kritisnya.

\section{SIMPULAN}

Hasil observasi dan analisis data yang sudah dilakukan, maka dapat disimpulkan yaitu keterampilan berpikir kritis siswa di SMP Negeri 6 Ngawi masih kurang. Hal ini dibuktikan dari rendahnya capaian nilai persentase tertinggi diperoleh sebesar 32\% dan persentase terendah sebesar $8 \%$ pada indikator keterampilan berpikir kritis. Dengan ketercapaian pada indikator keterampilan berpikir kritis adalah pada indikator mengatur strategi taktik dan indikator membangun keterampilan dasar. Berdasarkan nilai tes berpikir kritis pada kategori kurang $(\mathrm{K})$ dan sangat kurang (SK). Rendahnya kemampuan berpikir kritis siswa disebabkan karena siswa belum terbiasa dengan apa yang disajikan pembelajaran secara aktif yang dapat memaksimalkan suatu potensi berpikir siswa. Berpikir kritis merupakan salah satu keterampilan yang penting untuk dimiliki siswa.

Untuk mengembangkan keterampilan ini dalam proses pembelajaran guru harus menciptakan suasana serta strategi yang tepat. Strategi yang dapat dilakukan guru dalam suatu proses pembelajaran adalah dengan menciptakan suasana kelas yang menantang, mendorong adanya interaksi di antara siswa, serta melatih siswa untuk berpikir kritis. Hasil penelitian ini dapat memberikan suatu gambaran kepada guru dan peneliti tentang kondisi kemampuan berpikir kritis siswa di SMP. Selain itu, akan dilakukan penelitian lanjutan melalui media modul berbasis Problem Based Learning dalam upaya dapat melatihkan keterampilan berpikir kritis pada materi sistem pencernaan.

\section{DAFTAR PUSTAKA}

[1] R. Mason, "Literacy in the digital age," Br. J. Educ. Technol., vol. 37, no. 2, pp. 315-315, 2006, doi: $10.1111 / \mathrm{j} .1467-$ 8535.2006.00602_10.x.

[2] F. Kalelioğlu and Y. Gülbahar, "The effect of instructional techniques on critical thinking and critical thinking 
dispositions in online discussion," Educ. Technol. Soc., vol. 17, no. 1, pp. 248-258, 2013.

[3] J. Moon, Critical thinking: An exploration of theory and practice. 2007.

[4] R. H. Ennis, "The nature of critical thinking: outlines of general critical thinking disposition and abilities," Sixth Int. Conf. Think. MIT, vol. 2013, pp. 1-8, 2015, [Online]. Available:

http://criticalthinking.net/wpcontent/uploads/2018/01/TheNature-of-Critical-Thinking.pdf.

[5] P. a. Facione, "Critical Thinking: What It Is and Why It Counts," Insight Assess., no. ISBN 13: 978-1891557-07-1., pp. 1-28, 2011, [Online]. Available: https://www.insightassessment.com/ CT-Resources/Teaching-For-andAbout-Critical-Thinking/CriticalThinking-What-It-Is-and-Why-ItCounts/Critical-Thinking-What-It-Isand-Why-It-Counts-PDF.

[6] L. Handayani, "Peningkatan Motivasi Belajar IPA Melalui Model Pembelajaran Project Based Learning pada Masa Pandemi Covid19 bagi Siswa SMP Negeri 4 Gunungsari," J. Paedagogy, vol. 7, no. 3, p. 168, 2020, doi: 10.33394/jp.v7i3.2726.

[7] Lambertus, "Pentingnya Melatih Keterampilan Berpikir Kritis dalam Pembelajaran Matematika di SD," Forum Pendidik., vol. 28, no. 2, pp. 136-142, 2009.

[8] Kartimi, "Pengembangan Alat Ukur Berpikir Kritis pada Konsep Termokimia untuk Siswa SMA," $J$. Sci. Educ., vol. 1, no. 1, pp. 1-14, 2012.

[9] K. Karim dan N. Normaya,
"Kemampuan Berpikir Kritis Siswa dalam Pembelajaran Matematika dengan Menggunakan Model Jucama di Sekolah Menengah Pertama," EDU-MAT J. Pendidik. Mat., vol. 3, no. $1, \quad 2015, \quad$ doi: 10.20527/edumat.v3i1.634.

[10] S. Patonah, "Elemen Bernalar Tujuan pada Pembelajaran IPA Melalui Pendekatan Metakognitif Siswa SMP," J. Pendidik. IPA Indones., vol. 3, no. 2, pp. 128-133, 2014, doi: 10.15294/jpii.v3i2.3111.

[11] E. Poerwanti, "Konsep Dasar Asesmen Pembelajaran," Konsep Dasar Asesmen Pembelajaran, no. 1, pp. 1-44, 2015.

[12] L. Yuliati, "Efektivitas Bahan Ajar IPA Terpadu terhadap Kemampuan Berpikir Tingkat Tinggi Siswa SMP," J. Pendidik. Fis. Indones., vol. 9, no. 1, pp. 53-57, 2013, doi: 10.15294/jpfi.v9i1.2580.

[13] A. N. Khasanah, S. Sajidan, and S. Widoretno, "Effectiveness of critical thinking indicator-based module in empowering student's learning outcome in respiratory system study material," J. Pendidik. IPA Indones., vol. 6, no. 1, pp. 187-195, 2017, doi: 10.15294/jpii.v6i1.8490.

[14] R. Tauhid, "Dasar-Dasar Teori Pembelajaran," Pendas J. Ilm. Pendidik. Dasar, vol. 1, no. 2, pp. 32-38, 2020, [Online]. Available: http://jurnal.stkipkieraha.ac.id/index. php/pendas/article/view/109.

[15] C. J. Wenning, "The Levels of Inquiry Model of Science Teaching Wenning (2010) for explications of real-world applications component of the Inquiry Spectrum.) A Levels of Inquiry Redux," J. Phys. Tchr. Educ. Online, vol. 6, no. 2, pp. 9-16, 2010. 